\title{
観測時代の氷河・氷床の質量収支と 気候変化について
}

\author{
大村纂* \\ Mass Balance of Glaciers and Ice Sheets during \\ the Observational Period and Climate Change
}

Atsumu OHMURA*

\begin{abstract}
Glacier mass balance and secular changes in mountain glaciers and ice caps are evaluated from the annual net balance of 161 glaciers from 17 glacierized regions of the world. Further, the annual net balance is split into winter and summer balances for 35 glaciers of 11 glacierized regions. The global means are calculated by weighting glacier and regional surface areas. The area-weighted global mean net balance for the period 1960 to 2000 is $-250 \mathrm{mma}^{-1}$ w.e. ( -138 $\mathrm{km}^{3} \mathrm{a}^{-1}$ w.e.), with seasonal components of $1470 \mathrm{mma}^{-1}$ w.e. $\left(810 \mathrm{~km}^{3} \mathrm{a}^{-1}\right.$ w.e.) for winter and $-1725 \mathrm{mma}^{-1}$ w.e. $\left(-950 \mathrm{~km}^{3} \mathrm{a}^{-1}\right.$ w.e. $)$ for summer balances. The linear-fitted global net balance is accelerating at a rate of $-11 \mathrm{mma}^{-2}$. The main driving force behind this change is the summer balance with a rate of $-12 \mathrm{mma}^{-2}$. The decadal balance, however, shows significant fluctuations: melt reached its peak around 1945, followed by a decrease. The annual net balance, although negative for the global mean, approached equilibrium from the 1960s to 1980s. Some regions experienced a period of positive balance during this time, for example, Europe. The balance has become strongly negative since the early $1990 \mathrm{~s}$. These decadal changes correspond to periods of global dimming (for smaller melt) and global brightening (for larger melt). The total radiation at the surface changed as a result of an imbalance between steadily increasing greenhouse gases and fluctuating aerosol emissions.

The mass balance of the Greenland ice sheet and the surrounding smaller glaciers is negative at $-74 \mathrm{mma}^{-1}$ with an accumulation of $297 \mathrm{mma}^{-1}$ w.e. $\left(519 \mathrm{~km}^{3} \mathrm{a}^{-1}\right.$ w.e. $)$, melt ablation $-169 \mathrm{mma}^{-1}$ w.e. $\left(-296 \mathrm{~km}^{3} \mathrm{a}^{-1}\right.$ w.e. $)$, calving ablation $-181 \mathrm{mma}^{-1}$ w.e. $\left(-316 \mathrm{~km}^{3} \mathrm{a}^{-1}\right.$ w.e.) and the bottom melt $-21 \mathrm{mma}^{-1}$ w.e. $\left(-35 \mathrm{~km}^{3} \mathrm{a}^{-1}\right.$ w.e. $)$. At present, it is difficult to detect any statistically significant trends for these components. The total mass balance of the Antarctic ice sheet is considered to be too premature to evaluate.

The estimated sea-level contributions in the $20^{\text {th }}$ Century are $3.7 \mathrm{~cm}$ by mountain glaciers and ice caps, $3.5 \mathrm{~cm}$ by Greenland, $2 \mathrm{~cm}$ by ocean thermal expansion. The difference of $8 \mathrm{~cm}$ between these components and the estimated value with tide-gage networks $(17 \mathrm{~cm})$ must be caused by the mass balance of Antarctica and other sources that were not considered in the present work, for example, the melt of permafrost.
\end{abstract}

Key words : glacier, ice sheet, mass balance, climate change, radiation キーワード : 氷河, 氷床, 質量収支, 気候変化, 放射

\footnotetext{
* スイス国立工科大学大気気候研究室
}

* Institute for Atmospheric and Climate Research, Swiss Federal Institute of Technology (E.T.H.), Zurich, Switzerland 


\section{I. 序 論}

氷河に関する科学的な考察がはじめて記載され て 200 年余になる $(K u h n, 1787)$ 。氷河の形成 と変化は降雪を主とする涵養と融雪融水（極地で はさらに Calving が加わる）を主とする消耗の 上に成り立つ質量収支の結果である。したがって 気候と氷河の間にはきわめて密接な関係があり, この問題が定量的に論じはじめられてから 1 世 紀がたとうとしている（Mercanton, 1915）。そ して質量収支とそれを決める過程の研究が全球に わたって行われるに至ったのは国際地球観測年 （IGY, 1957 ～1958）以後であり，わずか半世紀 の観測結果と理論計算の経験しか持ち合わせてい ない。しかし， 20 世紀後半の半世紀は気候変化 と氷河変動のきわめて顕著でまた特異な期間でも あり，両者間の関係を学ぶのに適した期間でも あった。本論文の目的はまず全球で氷河の現状を つかみ，さらに，われわれが現在もちあわせてい る質量収支の観測結果をもとに 観測時代の氷河 質量変化を明らかにすることである。そして本論 文では気候変化との関係を踏まえて氷河質量収支 変動の原因を解明すると同時にその海水準への影 響を推定する。

\section{II. 世界の氷河の現状}

現在，地球上にある水河の総面積は 1,616 万 $\mathrm{km}^{2}$, その全容積は 2,843 万 $\mathrm{km}^{3}$ と推定されて いる（Ohmura, 2004; 藤井, 2005)。現時点での 水河の分布を表 1 に掲げる。グリーンランドと 南極大陸以外の水河容積は世界水河台帳の情報を 使いChen and Ohmura（1990）の方法で計算 された結果である。氷河の全球総面積はロシア連 邦の国土面積にほぼ匹敵し，容積は海面を $67 \mathrm{~m}$ 上昇させうる。氷河は地球上に存在する最大の淡 水貯水池といえる。便宜上, 水河に覆われている 地域を南極大陸，グリーンランド，そしてその他 の地域としょう。ここでいうその他の地域に存在 する氷河は南極大陸とグリーンランド以外に存在 するすべての水河を意味し，地理学的地域では 23 地域, 個々の水河数では約 20 万（面積 0.01 $\mathrm{km}^{2}$ 以上のもの）ほどにのぼり，ほとんどは山 岳水河と小規模な水冠である。この第 3 の範疇 に属する山岳氷河および氷冠は面積では全球水河 の $3.5 \%$, 容積で $0.3 \%$ ときわめて小さい。しか し, 小規模の氷河ほど気候の変化に敏速に反応す るため, 現在進行中の急速な温暖化のもとでは重 要な役目を果たすと考えられる。これらの氷河は 高度が低いものでは北極海および南極大陸周辺の 島嶼でみられるようにその末端が海面に達してい るものから，最も高所にみられるものはアタカマ 砂漠の東方のアンデス山脈で標高 $6,000 \mathrm{~m}$ を超 す所に末端をもつものまである。南極大陸とグ リーンランドのほかの 23 地域にある水河の面積 および体積を図 1 に示す。南極大陸とグリーン ランド以外で最も多くの水河が存在するのはカナ ダの北極諸島であり, 面積, 容積ともに $28 \%$ を 占める。北米大陸がそれに次ぎ $25 \%$ を占めてい る。したがって, 山岳氷河と氷冠の半分以上は北 米に存在するといってよい。なお，北極カナダに 現存する数多くの水冠は比較的低地に存在するも のが多くローレンタイド氷床の生き残りとみられ ている。バフィン島西部にあるバーンズ氷冠のよ うにかなり広い涵養域を有してまさにミニ氷床の ような振る舞いをみせているものもあるが, 多く は消耗域のみからなる特異な水河であり, 明らか に過去の寒冷期の名残である。このような水冠は 将来の温暖化を待たずに消滅する運命にあるもの と予想される。これら山岳水河と氷冠は以前思わ れていたほど厚くなく，平均の厚さ（全容積/表 面積）が $200 \mathrm{~m}$ に達していないことがわかった (Ohmura, 2009b)。平均の深さが $180 \mathrm{~m}$ で全容 積約 10 万 $\mathrm{km}^{3}$ いうことは海水準に換算して $26 \mathrm{~cm}$ である。こうした事実がわかるようになっ たのはレーダーによる探査の結果である。レー ダーが氷河に応用される以前の深度測定はもっぱ ら地震探査か手間のかかるボーリングによる直接 測定であり，どうしても深くなりがちな中央線に 沿って行われる傾向があった。また，面積の広い 涵養域で測定されることはきわめてまれであっ た。レーダーによってはじめて氷舌の横断面の形 状が正確に把握できるようになっただけでなく， 


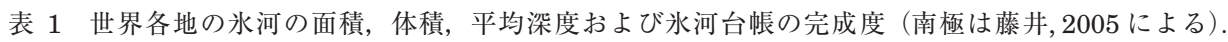

Table 1 Glacier area, ice volume, mean thickness and World Glacier Inventory completion rate (Antarctica is due to Fujii, 2005).

\begin{tabular}{|c|c|c|c|c|}
\hline Region & $\begin{array}{c}\text { Surface area } \\
\qquad 10^{3} \mathrm{~km}^{2}\end{array}$ & $\begin{array}{l}\text { Ice volume } \\
\qquad 10^{3} \mathrm{~km}^{3}\end{array}$ & $\begin{array}{c}\text { Mean } \\
\text { Thickness } \\
\text { m }\end{array}$ & $\begin{array}{c}\text { WGI } \\
\text { completion rate } \\
\text { in } \%\end{array}$ \\
\hline Greenland & 1,748 & 2,931 & 1677 & NA \\
\hline Iceland & 11.2 & 3.65 & 326 & 100 \\
\hline Scandinavia & 3.1 & 0.167 & 53.9 & 100 \\
\hline Alps & 3.1 & 0.146 & 47.1 & 100 \\
\hline Pyrenees and Cordillera Cantabrica & 0.011 & $10^{-4}$ & & 100 \\
\hline Jan Mayen & 0.116 & $10^{-2}$ & 25 & 0 \\
\hline Svalbard & 33.7 & 7.66 & 227.3 & 100 \\
\hline Zemlya Frantsa Yosifa & 13.759 & 1.907 & 138.6 & 100 \\
\hline Novaya Zemlya & 23.645 & 11.133 & 470.8 & 100 \\
\hline Severnaya Zemlya \& Ostrov Ushakova & 19.366 & 6.603 & 341 & 100 \\
\hline Ostrava de Longa, Novosibirskiye Ostrova & 0.081 & 0.007 & 86.4 & 100 \\
\hline Ostrov Vrangelya & 0.004 & 0.000033 & 8.3 & 100 \\
\hline Caucasus & 1.39 & 0.066 & 47.5 & 100 \\
\hline Severniy Ural & 0.018 & 0.00037 & 20.6 & 100 \\
\hline Ex-SU in Asia & 23.855 & 4.217 & 176.8 & 100 \\
\hline Canadian Arctic Islands & 151.758 & 27.56906 & 181.8 & 17.3 \\
\hline North America (continental, excl. Alaska) & 49.609 & 4.5825 & 92.3 & 21.3 \\
\hline Alaska & 74.722 & 20.45017 & 273.6 & 16.4 \\
\hline Mexico & 0.011 & & & 0 \\
\hline Afganistan, Iran, Turkey & 4.044 & 0.14569 & 36 & 11.7 \\
\hline India, Pakistan & 40 & 3.07622 & 76.9 & 4.7 \\
\hline Bhutan, Nepal & 7.34 & 0.74046 & 100.9 & 40.7 \\
\hline China & 59.425 & 5.6 & 94.2 & 100 \\
\hline Indonesia & 0.007 & & & 0 \\
\hline Africa & 0.011 & $10^{-4}$ & & 0 \\
\hline New Zealand & 1.158 & 0.062 & 53.5 & 100 \\
\hline South America & 25.855 & 1.9432 & 75.2 & 17.9 \\
\hline Sub-Antarctic islands & 7 & 1.2 & 171.4 & 0 \\
\hline Antarctica & 13,860 & 25,400 & 1,833 & NA \\
\hline Total & 16,158 & 28,432 & 1,760 & \\
\hline of which outside Antarctica \& Greenland & 550.241 & 100.926 & 183 & \\
\hline
\end{tabular}

Bold figures are based on completed WGI, while regular figures are due to partially done WGI.

比較的浅いが面積の大きな涵養域が広範囲にわ たって多くの氷河で探査されるようになったので ある。氷河の深さ (容積) を正確に把握すること は, 今後の水河存続, 消滅を予測するためのみな らず水河の海水準への影響を正確に理解するため に最も重要なことである。

\section{III. 水河質量収支の観測とデータ}

\section{1）質量収支測定方法と誤差}

水河の質量収支を最も正確に把握するには, 水 河の表面において出入りする質量束を直接測定す ることが重要である。頻繁に使われる方法は, 水 河の表面に垂直に固定した杭に対する氷河表面の 


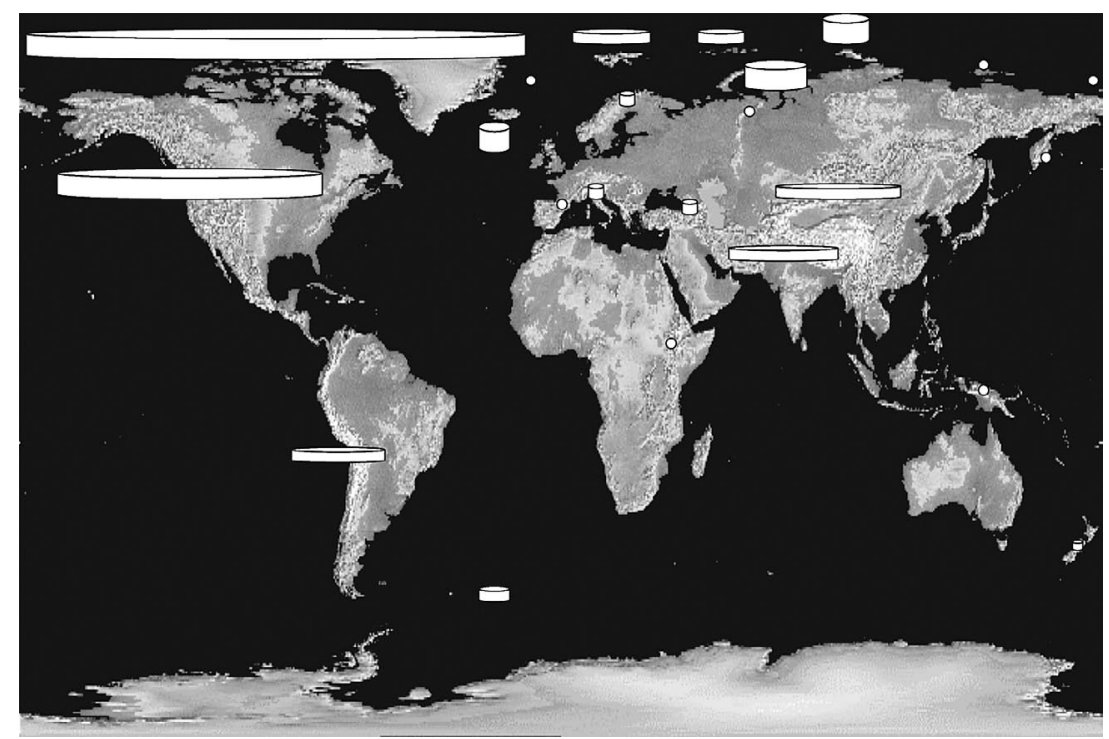

図 1 地域別水河面積, 容積㧍よび平均の梁さ。表 1 に掲げた 28 地域のうちアラスカ, 北米, メキシコおよ びインド，パキスタン，ブータン，齐パールおよびコーカサス，アフガニスタン，イラン，トルコは それぞれ一地域としてグルーピングされている。それぞれの地域の水河の総面積は円柱の底面の面積 に，容積は円柱の容積に，水河の深さは円柱の高さに比例して表現されている.

Fig. 1 Regional surface area, volume, and mean depth of glaciers. Of 28 glacierized regions, the following regions are categorized each into one group: Alaska, North America, and Mexico; India, Pakistan, Bhutan, and Nepal; Caucasus, Afghanistan, Iran, and Turkey. The base and height of the column are scaled proportional to the area and mean depth of the glaciers, hence the column volume indicates the total regional ice volume.

位置変化から単位面積についての質量の増減を決 める方法であり, Stake Method と呼ばれている。 この方法の精度は設定される杭の密度に依存する が，中緯度および高緯度の谷水河の場合 $1 \mathrm{~km}^{2}$ に 1 本くらいが望ましい。測定の時期は涵養期 の終わりと消耗期の終わりであり，後者の測定時 はできれば水文収支年の終わりである秋，9月の 末（南半球では 3 月末）にあわせるよう努力さ れるが，実際には天候やロジスティックスの都合 に支配され多少の変動は致し方ない。測定誤差は 冬季の降雪と地吹雪の堆積の場所による不均一さ に最も大きく影響されるが，熟練した測定であれ ば，士水柱 $5 \mathrm{~cm}$ には収まろう。チューリッヒに ある世界氷河モニターサービス（World Glacier Monitoring Service) に現在報告されてくる質量 収支のデータはほとんどこの方法による。Stake Method は精度は高いが，大変手間がかかるため 大きな氷河になると，1 時期を期するべき短時間
内（長くて 1 週間）の測定が難しくなる。

こうした場合には, Hydrological Balance Method が用いられる。これは対象の水河を含む 分水界全体の水文収支の貯蔵項を除いた全項を測 定し，収支の未決算としてでてくる貯蔵項を質量 収支として仮定するものである。そのため，流出 量測定の施設など多額の投資が必要であり，その 割にはStake Methodに比べて䛊差が大きく $10 \mathrm{~cm}$ は覚悟せねばならない。アルプス最大のア レッチ水河はクラリーデンフィルン $(1914 / 15$ 年 $)$ についで世界で 2 番目に長い観測歴（1922/23 年）をもつが，この方法で行われてきている。表 面積 $82 \mathrm{~km}^{2}$, 全長 $25 \mathrm{~km}$ もあり, Stake Method は事実上不可能であるから致し方ない。

第 3 の方法として測地学的方法というのがあ る。これはある期間で隔てられた 2 時点におけ る水河全体の高度を比べることにより求まる相対 体積変化から水河全体の質量収支を計算する方法 
である。2 時点の比較に必要な時間的間隔は高度 測定の誤差と年質量収支の比に比例するが，ヨー ロッパの水河では $5 \sim 10$ 年の間隔がとられる。 現在では衛星に搭載されている高度計も使えるよ うになった。しかし測地学的方法の原理から自明 のごとく，この方法は氷河全体を扱わないと意味 をなさない。それは氷河上の 1 点ないし 1 部分 の高度変化はそこでの質量収支に氷河の流動の垂 直成分が加わった量であり両者の分離が難しいか らである。この方法は氷河の全表面を積分するこ とによって流動垂直成分が消去され質量束が残る 性質を利用するものである。このようなきわめて 基本的なことをここで繰り返すのは，とくにリ モートセンシングの専門家の間ではこのことがい まだに理解されておらず，後に述べるようにグ リーンランドや南極水床の 1 部 1 地域の標高差 を即質量収支とする論文が昨今乱造されている ためである。

質量収支の正確な把握は理想的には，上記の 3 方法が同時に併用されることである。しかしこれ は限られた手段で研究を進めなければならない現 状では困難であり，世界で唯一 3 つの方法を併 用して 30 年以上測定が継続されているのは, オーストリアにあるフェルナグトフェルナーのみ である。

\section{2）質量収支観測データの現状}

質量収支は氷河の大きさを決める最も重要な要 素である。したがって，その観測は氷河の長さや 面積の測定などに比べて本質的な意味をもつ。し かし，質量収支の測定は長さや面積などの観測と 比べて, 桁違いの時間, 労力, 経験, 資金が必要 である。このため本論文に使用されたデー夕は World Glacier Monitoring Service に保存されて いるもののほか，長年それぞれの水河の観測を続 けている研究者から直にいただいたものである。 現在，世界中で 1 ～ 2 年というごく短期の測定 を含めて質量収支が測られたのは 400 程の水河 である。水河の現気候下における特性としての平 均質量収支を得るには少なくとも 5 年から 10 年 の観測が必要であるが，この条件に適う氷河は 161 である。さらに年質量収支の永年変化をみる
には最低で 30 年の観測は必要であり，これに適 う水河は全世界で 50 強しかない。また氷河の質 量収支変化と気候の関係を理解するには年収支た けでは不可能である。それは，年収支は冬季収支 と夏季収支の和であり，冬季収支と夏季収支の観 測時期はおのおの，年涵養量と年消耗量をできる だけ近似できるように設定されている。年涵養量 は多くの場合，冬季の降雪量で決まる。夏季消耗 量はほとんど年融雪融水量で決まる（ただし，数 は少ないが赤道地域, 乾燥地域の高山, 南極ドラ イヴァレーの氷河はこの傾向から外れる)。降雪 と融雪はまったく異なった過程であり，両者の和 を理解するにはそれぞれの過程の結果である冬と 夏の収支が必要となる。現時点において冬季収支 と夏季収支が 30 年以上にわたって連続観測され ている氷河は 35 存在する。

これら 35 の氷河は北半球だけに存在するため, 地理的に非常に不均一な分布を示す。もう 1 つ 重要なバイアスがある。質量収支の測定対象とさ れる水河はどちらかというと涵養量の少ない氷河 である。とくに冬季収支が計られる水河では，積 雪の大きさが障害となり事実上長期にわたる測定 活動を維持することは難しい。現在連続観測され ている 35 の水河のうち, 冬季収支が水柱 3,000 $\mathrm{mm}$ を超える水河はカナダのセンチネル水河, ノ ルウェー西岸に面するアルフォトブレンとエンガ ブレンの 3 氷河に過ぎない。水柱 $3,000 \mathrm{~mm}$ の 積雪というとフィールドでの状態では $7 \sim 8 \mathrm{~m}$ の厚さになる。こんなに深いピットを短時間で少 なくとも数力所で掘って雪の密度を計り，作業の 後にはピットを埋めてまた元どおりにすることは 困難であろう。また多雪域は概して雪崩の危険が 多い所でもある。したがって，こうした地域での 質量収支の測定にはリモートセンシングが最も適 している。

\section{IV. 山岳水河および水冠の年質量収支の 永年変化}

\section{1）年質量収支の変動}

まず短期の測定を含めて，比較的質の高いデー 夕がある 161 の水河の年質量収支を世界の 17 の 


\section{Global and regional mean annual net balance}

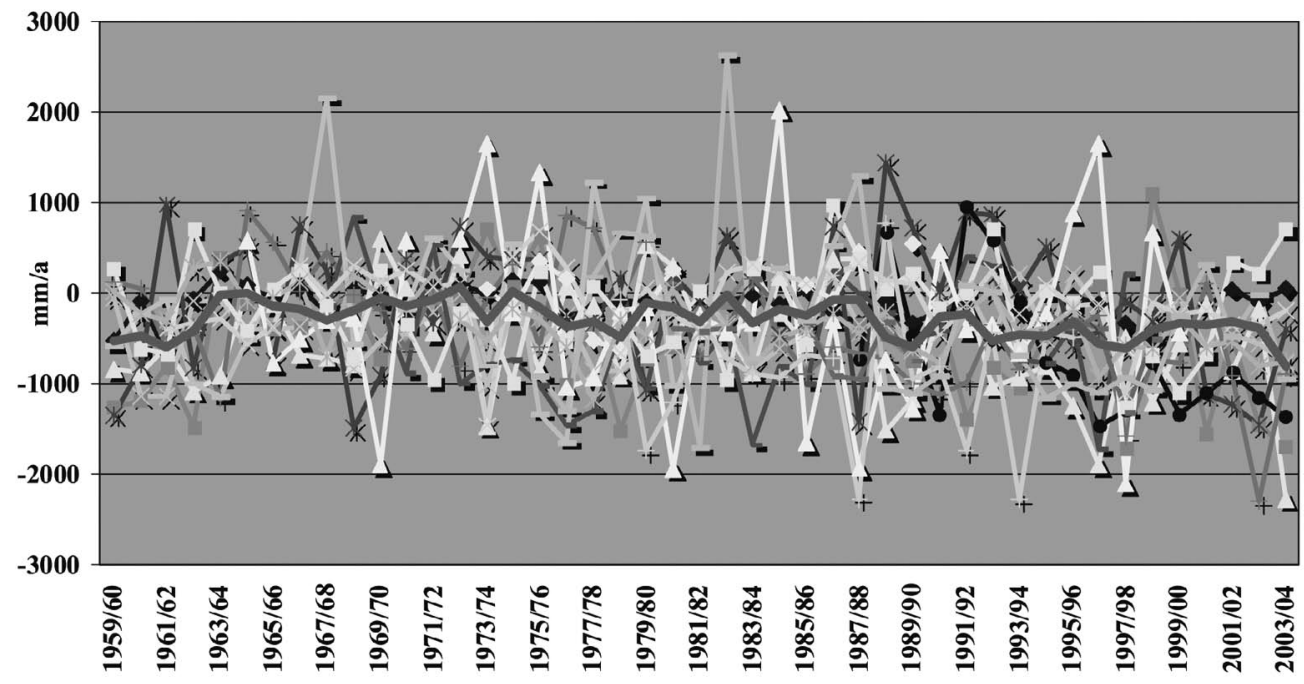

$\begin{array}{lll}- \text { Cnd Arctic } & - \text { West coast NA } & \text { Alaska } \\ \text { Svalbard } & \text { - Scandinavia } & - \text { Iceland } \\ - \text { Alps } & \text { Ural } \\ \text { Severnaya Z. } & \text { Pamir } & \text { Kamchatka } \\ - \text { Altai } & \text { Caucasus } & \text { Africa } \\ - \text { Himalayas } & \text { Andes } & \text { Area weighted global mean }\end{array}$

図 2 世界の 17 地域の過去 45 年にわたる年質量収支. これらの地域は北極カナダ, 北米西海岸, アラスカ, スヴァルバール，スカンディナヴィア，アイスランド，アルプス，パミール，ウラル山脈，七ヴェルナ ヤゼムリ，コーカサス，カムチャッカ半島，アルタイ山地，天山山脈／ズンガリア山地，アフリカ，ヒ マラヤ山脈, アンデス山脈である。太線は地域の面積でウェイトを掛けた世界平均を示す（口絵 2-図 1 参照; 大村, 2010).

Fig. 2 Annual mean net balance over 45 years for the following 17 regions: Arctic Canada, North American Cordillera, Alaska, Svalbard, Scandinavia, Iceland, Alps, Pamir, Urals, Severnaya Zemlya, Caucasus, Kamchatka, Altaishan, Tienshan/Dzungaria, Africa, the Himalayas, and the Andes. The bold line indicates the area-weighted global mean (see to Pictorial 2-Fig. 1; Ohmura, 2010).

氷河地域に分けて図 2 に示す。重要な特徵は, 比較的大きな地域別の年々の変化に重ねて，全地 域が驚くほど類似した永年傾向を示していること にある。この 17 の水河地域の水河面積のウェイ トを掛けた世界平均をみると 1950 年代の終わり 頃から 60 年代のはじめの頃は年 $500 \mathrm{~mm}$ 程の負 の収支である。これより以前の状況は後ほどデー 夕の豊富なヨーロッパの水河で検討しょう。その 後 1980 年代の後半までの 25 年間負ではあるが 絶対值の比較的小さな，したがって平衡状態に近 い期間がある。この間の平均収支は $-215 \mathrm{~mm}$ である。その後, 1990 年代に入ってからは大き
な負の収支に転じ，しかも負の傾向は加速されて おり，2000 年以降は年 $-500 \mathrm{~mm}$ を超す大きな 負の収支になっている。この間の事情を正確を期 するために 5 年ごとの平均值にして表 2 に掲げ る。このように過去の 45 年間は概して負の収支 であった。負の収支のうちにも顕著な変動があり その変動範囲はおよそ年 $800 \mathrm{~mm}$ である。

このように $1960 ２ 000$ 年代に至る比較的短 い期間に，氷河質量収支の世界平均值はほぼ均衡 に近い収支から，現在の大きな負の収支に移行し ている。それでは 1960 年以前はどうであったの だろう。この問いに対して答えうるのは観測歴の 
表 21960 年以降の特定水河における 5 年ごとの質量 収支の変動。図 2 に掲げた 17 の水河地域 161 水 で河の面積のウェイトを掛けた世界平均. 1961 年以後の 5 年ごとの平均值. 単位は水柱 $\mathrm{mm}$.

Table 2 Area-weighted global mean mass balance of 161 glaciers from 17 glacier-covered regions arranged for pentade means. Unit is mm w.e.

\begin{tabular}{cc}
\hline Pentade period & Annual mass balance \\
\hline $1960 / 61-1964 / 65$ & -131 \\
$1965 / 66-1969 / 70$ & -132 \\
$1970 / 71-1974 / 75$ & -140 \\
$1975 / 76-1979 / 80$ & -247 \\
$1980 / 81-1984 / 85$ & -232 \\
$1985 / 86-1989 / 90$ & -332 \\
$1990 / 91-1994 / 95$ & -317 \\
$1995 / 96-1999 / 00$ & -426 \\
$2000 / 01-2004 / 05$ & -444 \\
\hline
\end{tabular}

長いヨーロッパの氷河においてのみである。アル プスにある 19 の氷河とピレネーの 1 氷河の年平 均収支とその経年変化を図 3 に掲げる。1960 年 以前には 1948 年を中心にかなり顕著な負の収支 の期間があった。図 2 に示した 1950 年代末〜 60 年代初頭の大きな負の収支世界平均はやはり 偶然ではなく，この大きな負の時期の終わりに近 い所を捉えていたのである。1965 年から 70 年 までほぼ均衡状態の 5 年間がある。その後 1980 年まで，10 年間，収支が正に転じた期間があっ た。この期間にはヨーロッパでは $60 \%$ 以上の水 河が前進する。1980 年代のはじめ以降現在まで は急速に負に転じている。正の頂点から負の谷 底までの変動範囲は大きく，何と年 $1300 \mathrm{~mm}$ に 達する。アルプスとピレネーにおける氷河の質量 収支は 1960 年から 2005 年の 45 年間に関して は図 2 に掲げた世界平均と比べることができる。 アルプス氷河の変動の振幅は大きいが一旬単位で 現れる増減のトレンドは実によく一致している。 それではどのようにしてこのような変動が起こっ たのであろうか。年質量収支は 2 つの成分であ る涵養と消耗または冬季収支と夏季収支から成り 立っている。したがって，この 2 成分を個々に みなければならない。

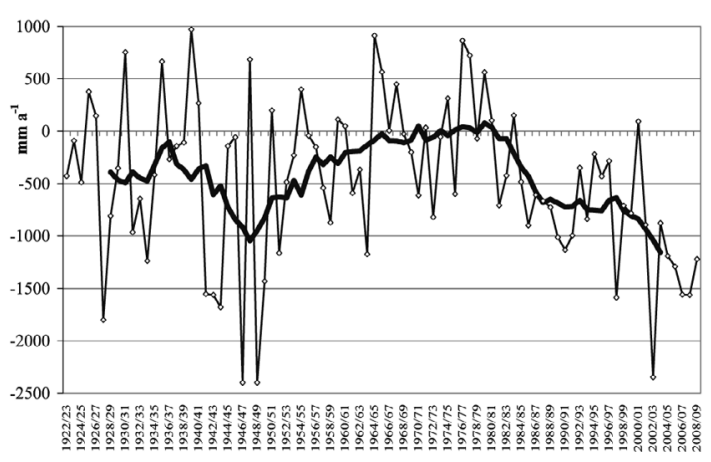

図 3 アルプスとピレネーにある 20 の水河の年質量 収支の平均值. 11 年の経年平均は太線で示さ れる. 単位は水柱 $\mathrm{mm} /$ 年.

Fig. 3 Mean annual net balance of 20 glaciers in the Alps and the Pyrenees. The bold line indicates an 11-year running mean. Unit in mm w.e./a.

\section{2）冬季収支および夏季収支の変動}

III 章 2)節 で述べたように，冬季，夏季収支 を長期間観測している氷河は 35 ある。図 4 はこ れら 35 の水河の冬季，夏季および年収支をそれ ぞれの地域の氷河面積のウェイトを掛けた平均値 で $1961 〜 2005$ 年までを集計したもので，本論 文で最も重要な図である。これらの水河は図 4 の説明に掲げる 11 の地域に分布する。アンデス, ヒマラヤ，アイスランドにはこうした計算に使え

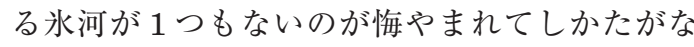
い。氷河の数も地域も限られたサンプルになるの で，まず図 4 の中程の年正味質量収支（灰色の 線) がどのくらい最大の水河数（161 水河）と地 域数（17）で計算された正味質量収支に近いか テストする。後者は図 2 に表されているように すでに計算済みであり，図 4 では中程の黒線で 表されている。両者はほとんど同一とみなしてよ いであろう。とくに 11 年移動平均と 45 年トレ ンドは区別が難しいくらい近い。この事実は氷河 の長期変動はグローバルの気候変化に強く影響さ れていることを意味する。そして，今扱われてい るわずか 35 の氷河の変遷がグローバルな現象を かなり捉えているといえる。

まず 1960 年代の前半は質量収支がゼロに近く 地球全体としてみると水河は気候と程よく釣り 


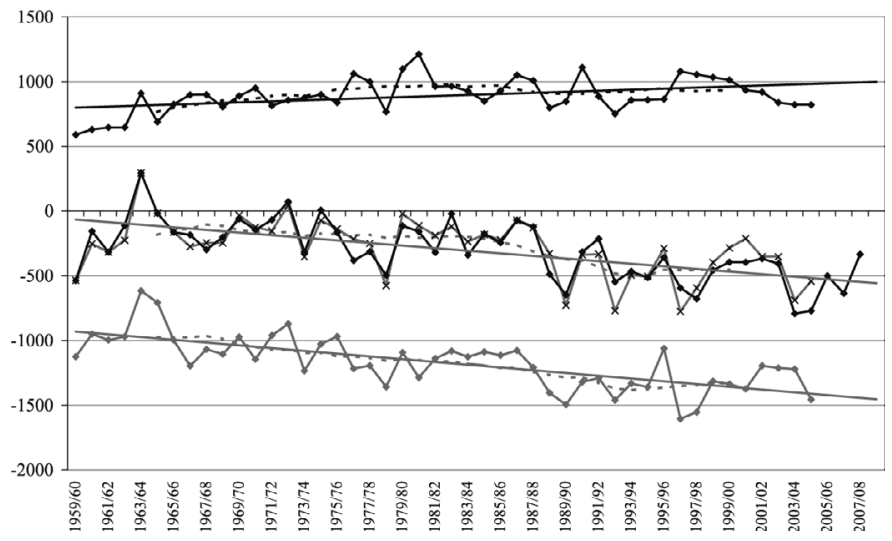

図 4 世界の 11 地域 35 水河の面積ウェイトを掛けた冬季，夏季，および年平均質量収支. 図の上方の線は 冬季収支（実線とダイアモンドはその年の冬季収支, 点線は 11 年の移動平均, 長い線分は 45 年のト レンドを意味する)。図中程の灰色の線は年収支(正味収支), 図下方の線は夏季収支を意味する。さ らに図中程の黒線は図 2 で説明された 17 地域 161 の水河に基づく世界平均質量収支である. 灰色線 がこの黒線にきわめて近いことは，35 と数では少なく，地域でも 11 と限られているが，ここで扱わ れた季節別の質量収支はかなりよく世界平均を近似していることを示す.これらの地域は北極カナダ, 北米西海岸，アラスカ，スヴァルバール，スカンディナヴィア，アルプス，パミール，コーカサス，カ ムチャッカ半島, アルタイ山地，および天山山脈/ズンガリア山地である。単位は水柱 $\mathrm{mm} /$ 年.

Fig. 4 Area-weighted global mean annual mass balance, based on 35 glaciers in 11 regions. Three groups of lines are from the top the winter balance; middle the annual net balance; and bottom the summer balance. Each group is made of three lines, a solid line with diamonds (annual balance), a broken line (11-year running mean) and a definite straight line (linear trend). The grey line in the middle representing the global areaweighted mean annual net balance of 161 glaciers from 17 regions is given for comparison. The closeness between the grey and black lines supports the global significance of the 35 glaciers in 11 regions, for which winter and summer balances are observed. These 11 regions are Arctic Canada, North American Cordillera, Alaska, Svalbard, Scandinavia, Alps, Pamir, Caucasus, Kamchatka, Altaishan, and Tienshan/Dzungaria. Unit in $\mathrm{mm}$ w.e./a.

合った均衡状態にあったといえる。時代をさかの ぼって観測データのあるヨーロッパの氷河（アル プスでは 1920 年代，スカンディナヴィアでは 1940 年代から）をみると地域によるフェイズの 相違はあっても，1940 年代半ばを中心に質量収 支の負の時代があり，60 年代か 70 年代に収支ゼ ロないし正の時期を認識することができる。気候 温暖化の 20 世紀といわれるなかで, 少なくとも 消耗の止まった時があったということは重要であ る。そして 1990 年頃からはかなり加速気味の質 量峦失状況を示している。この 45 年間の平均質 量収支は年水柱で $-250 \mathrm{~mm}$, 加速率は -11 $\mathrm{mma}^{-2}$ となる。またこの年収支トレンドは夏季 収支の変化の結果であることがわかる。4 5 年間 の平均夏季質量収支は- $1690 \mathrm{~mm}$ で，その傾向 は負の加速でー $12 \mathrm{mma}^{-2}$ であり，永年にわたる
年収支のトレンドはほとんどすべて夏の融雪融水 の結果といってよい。これにひきかえ，冬季収支 は 45 年間を通じてほとんど一定であったといえ る。

ヨーロッパの水河地域の気温の歴史をみよう。 図 5 はアルプスとスカンディナヴィアからそれ ぞれ氷河に近い 6 高山測候所を選び夏の 6 月, 7 月，8月の平均気温を示した。これによると，比 較的寒冷な 1920 年代から約 $1{ }^{\circ} \mathrm{C}$ 昇温して 1940 年を中心に 15 年間ほど温暖期を迎える。その後 1950 年より 1980 年まで 30 年間の寒冷期がくる。 1980 年以降 $1^{\circ} \mathrm{C}$ 強増加している。これらの温度 変化のフェイズは上記の 1940 年代の負収支, $1960 \sim 70$ 年代のゼロ収支そして最近の加速的 な負の期間に一致する。さらに詳細に比べると フェイズは一致しても振幅にちがいがある。 


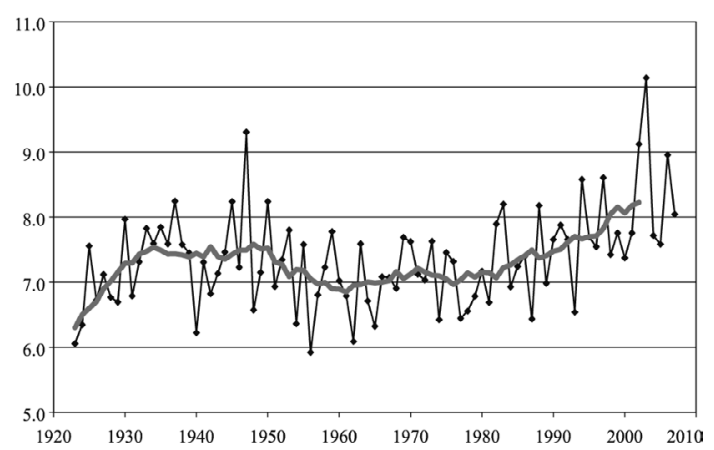

図 5 ヨーロッパ水河地域の夏の平均気温. ノル ウェーのアビョルスブラテン (601 m a.s.l.), キョレムスグレンデ (626 m a.s.l.)，フォクス ツグ (972 m a.s.l.)，スイスのサンクト-ベルナ ルド峠 (1639 m a.s.l.) およびセンティス $(2490 \mathrm{~m}$ a.s.l.), オーストリアのゾンブリック (3105 m a.s.l.) の 6 月， 7 月， 8 月の平均気温（細線） とその 11 年移動平均 (太線).

Fig. 5 Summer air temperature for glacierized region of Europe. The thin line represents the mean values of six stations, Abjorsbraten, Kjoremsgrende, and Fokstugu of Norway, St. Bernardo of Switzerland, and Sonnblick of Austria. The bold line is the 11year running mean.

1940 年代の温暖期は 21 世紀に比べると $0.5^{\circ} \mathrm{C}$ 程 低温であった。しかし，質量収支の負の度合いは 21 世紀に勝るとも劣らない。それは, 後に述べ る大気の透過度の永年変化の影響であり，1950 年代以前には大気の透過度が現在より高く太陽放 射が多かったためである。

もう少し詳細にみてみよう。冬季収支は 1990 年まではわずかに温度に比例して増加した。この 傾向はほとんどの地域で見いだされている。これ は温暖化による全球的な蒸発散量の増加による。 この傾向は, 全球的にみた降水量によくうかがえ て今でも増加傾向にある。ところが，多くの地域 で 1980 年代の後半から昇温のため降雪になる割 合が減少している。この冬季の降雪の減少が涵養 量の減少となって現れなおも進行中である。一 方, 夏季収支に現れている融雪融水は 1970 年代 にいったん底をうちアルプスで経験されたように 地域によっては減少した所も多い。融雪融水は 1990 年代に入ってからは再び増加に転じている。 最近の 10 年間は涵養の減少と消耗の増加によっ
て正味収支は観測開始以来最大の消耗率を示すよ うになった。この間の収支状態を 5 年ごとに集 計して表 3 に示す。 2000 年代に入ってからの平 均正味収支は水柱で年約 $45 \mathrm{~cm}$ の負であり IHD (International Hydrological Decade, 1965 1974）の 10 年間の頃の 3 倍にもなっている。こ の融水は海水準を年 $0.7 \mathrm{~mm}$ 上昇させることにな $り$, 雪水圈の 海水準変化への最も重要な役割の ひとつといえよう。

小水期を脱した 20 世紀全体をみてみよう。現 在まで継続されている質量収支の長期観測はほと んど第二次大戦以後に開始されたのであるが，数 はきわめて少ないがアルプスのローヌ氷河, クラ リーデンフィルンやアレッチ水河のように 19 世 紀の終わりに近い第一次国際極地観測年 $(1882$ 〜 1883）または 20 世紀のはじめから観測されて いる (Chen and Funk, 1990; Aellen, 1995; Ohmura, 2006）氷河の 20 世紀前半と後半を比べる と，両半世紀は量的にきわめて近い年収支より なっていることがわかる。もしこの傾向がすべて の水河地域で同様であったと仮定すれば，20世 紀全体の海水準への影響は約 $4 \mathrm{~cm}$ となる。

ここで気候変動と氷河質量収支の関係で重要な 問題は, 温室効果ガスの増加による温暖化が進行 中であった 20 世紀の中に 1960 年代から 1980 年 代の 30 年間にもわたって何が原因で負の収支が 伸び悩んだのかという問題である。この伸び悩み は夏季収支，すなわち融水の停滞によるものであ り，事実この間，温暖化は停止して，わずかなが らも寒冷化に移行したのである。これは先の図 5 でヨーロッパの氷河地域で指摘された現象であ り，また観測值に基づく全球気温をそれぞれ個別 に計算しているNOAA，NASA，ECMWF（European Centre for Medium-Range Weather Forecasts) や CRU (Climate Research Unit, University of East Anglia）などの結果にも共通に現れ ている現象で, 温暖化の原因を正しく理解するに はこの寒冷化をも理解しなければならない。20 世紀の後半に起こったこの寒冷化は第二次大戦後 の復興と経済成長期につくられたエアロゾルによ るもので，工業国がまずは大気污染を抑制する目 
表 3 冬季, 夏季質量収支が長期にわたって行われている 35 の水河にお ける 5 年ごとの平均季節および年収支. 5 列目は年正味収支のみ計 られている 161 の水河での結果を比較のために掲載. 単位は水柱 $\mathrm{mm}$.

Table 3 Area-weighted global mean winter $(\mathrm{Bw})$, summer $(\mathrm{Bs})$, and annual $(\mathrm{Bn})$ mass balances of 35 glaciers from 11 regions arranged for pentade means. The last column contains the pentade means of the annual balance including glaciers with only annual balance observations. Unit is mm w.e.

\begin{tabular}{crccc}
\hline Pentade period & Bw & Bs & Bn & Bn 161 glaciers \\
\hline $1960 / 61-1964 / 65$ & 685 & -848 & -163 & -131 \\
$1965 / 66-1969 / 70$ & 835 & -1068 & -233 & -132 \\
$1970 / 71-1974 / 75$ & 881 & -1048 & -167 & -140 \\
$1975 / 76-1979 / 80$ & 944 & -1166 & -222 & -247 \\
$1980 / 81-1984 / 85$ & 1003 & -1144 & -141 & -232 \\
$1985 / 86-1989 / 90$ & 914 & -1260 & -346 & -332 \\
$1990 / 91-1994 / 95$ & 885 & -1353 & -468 & -317 \\
$1995 / 96-1999 / 00$ & 984 & -1374 & -389 & -426 \\
$2000 / 01-2004 / 05$ & 892 & -1292 & -400 & -444 \\
\hline
\end{tabular}

的で大気の浄化に乗り出すまで続く（Ohmura and Lang, 1989)。図 6 はこの期間に起こった全 球平均で $8 \mathrm{Wm}^{-2}$ におよぶ太陽放射の減少を示 し,この現象は Global dimming と呼ばれてい る。大気浄化の効果は 1990 年以降の大気の透過 度の改善（増加）となって現れ，そのため太陽放 射も増加することになり, 進行中の温室効果と相 まって，観測史上最大の昇温率を示すことになる (Wild et al., 2003, 2005)。この時期の太陽放射 の増加はやはり $8 \mathrm{Wm}^{-2}$ であり Global brightening と呼ばれている。現在進行中の温暖化は, 実は大気長波放射の強化を引き起こす温室効果ガ スの増加と太陽放射を遮蔽するエアロゾルの変化 の間のバランスのわずかな崩れによって成り立っ ていることがわかる（Ohmura, 2009a）。した がって，近い将来，人間活動が人為的な温室効果 を上回るエアロゾルをつくる方向に動けば，寒冷 化が起こる可能性は十分あることになる。もし， そうなったとしても，温室効果を過小評価しては ならない。温室効果ガスとエアロゾルは大気中で の滞留期間に大きな差があり，滞留期間の短いエ アロゾルの大気中での濃度は早い時期に頭打ちに なるのに対して, 温室効果ガスは何百年と蓄積す

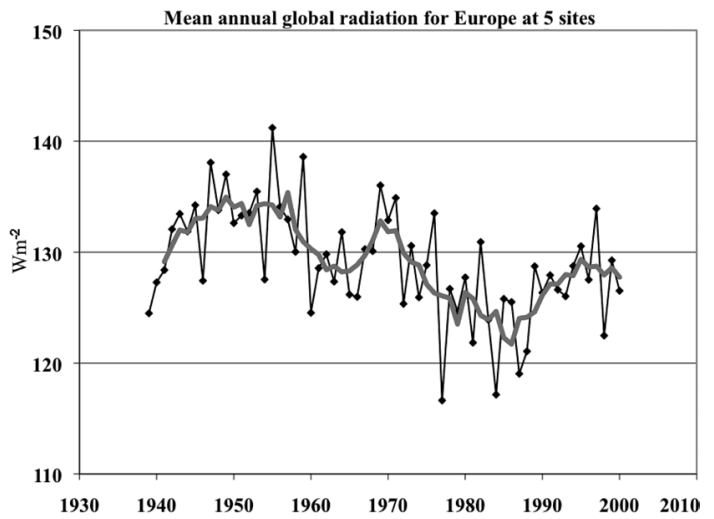

図 6 年平均全天太陽放射. 世界で最も長い観測実 績を有するストックホルム，ヴァゲニンゲン， ダヴオス，ポッダム拈よびロカルノ-モンティ の平均值.太線はその 11 年移動平均値.

Fig. 6 Mean annual global solar radiation for 5 European sites (Stockholm, Wageningen, Davos, Potsdam, and Locarno-Monti) with the longest observation records. Thin line indicates annual means, while the bold line is the 11-year running mean.

る。長い将来を考慮するほど, 温室効果ガスの重 要性は増すのである。 


\section{V. 水床の質量収支}

\section{1）概況と資料}

現在，地球上には南極水床とグリーンランド氷 床という 2 つ氷床がある。この 2 水床はそれ ぞれ全水河面積の 86 および $11 \%$ 占める。一義 的には氷河の質量収支は表面積に比例した影響力 をもっているといわれる。しかしながら全球的水 河の質量収支のなかでの重要さは，単に面積だけ には比例せず，質量フラックスの大きさにも比例 するので，収支率の比較的小さな極地の氷河は面 積の割りには全球への影響は限られている。これ までの質量収支の研究からこの 2 つの水床を比 ベると, グリーンランド氷床研究はかなり精度の 高い領域に達しており，ここに重点を置いて議論 を進める。

まずグリーンランド氷床の質量収支研究の歴史 を概観し，続く節で氷床質量収支にかかわる研究 から必要な資料を選ぼう。グリーンランド氷床の 質量収支研究はおよそ 1 世紀の歴史をもつ。ま ず 1912 年にスイスーグリーンランド横断探検隊 はグリーンランド西岸北緯 $70^{\circ}$ からほぼ南東に向 け $700 \mathrm{~km}$ ，アンマサリクまで横断し，その行程 で 28 地点の涵養量を測定したのがはじまりであ る (Quervain and Mercanton, 1920)。その後も 第二次大戦までの間に，第二次国際極地観測年な どがあったのだが，グリーンランドでは単発的な 現地調査しか行われなかった。体系だった涵養量 に関する調査はIGYの時にはじめて行われた (Benson, 1962)。これらはピットにおける積雪 層序学によるもので, 試料の長さに限りがあり, 10 年以上のデータはほとんど得られなかった。 消耗量を全グリーンランドにわたって求めるため には氷河学的直接質量収支の測定と気温の季節変 動の資料が必要なため, 1980 年代まで先送りさ れた（Ohmura, 1987）。さらに極地水河に特有 の Calvingによる消耗量の推定には海面付近で の流速と氷河断面の情報が必要であり, これが広 い範囲に扱われたのは 1990 年代になってからで あった。しかしその後の進歩は速く，現在では質 量収支の各項はかなり信頼性をおいてよいまでに
解明されている。

\section{2）グリーンランド氷床の質量収支}

Benson（1962）以後の涵養量に関する情報の 蓄積には目覚ましいものがある。その第 1 の原 因はとくにこの 40 年程の間に多くの氷のコアが とられ，ピットからの試料とは比べものにならな い長い期間が扱えるようになったことである。第 2 はコアーの年代測定法の進歩である。コアーに しろ深いピットにしろ，このように直接氷河上で 涵養量が量れるのは融雪によって質量の失われな い高度帯であり, Benson (1961) と Müller (1962) の定義によるUpper percolation zone 以上の地 帯になる。したがって, Lower percolation zone 以下の涵養域と消耗域全体の涵養量はUpper percolation zone 低部の涵養量と水河の外にある 測候所で計られた積雪量とで内挿される。Benson 以後グリーンランド全域にわたって涵養量の 正確な把握に寄与した論文には Reeh and Olesen (1986), Ohmura and Reeh (1991), Calanca et al. (2000), Ohmura et al. (1999), Bales et al. (2009), Box et al. (2006) などがある。こ れらを総合することによって現時点での最も正確 な涵養量が求められる（図 7）。

融水および融雪の消耗量の実測は 1982 年にグ リーンランド地質調査所によってはじめられた。 このプロジェクトは元来, グリーンランド氷床の 水力発電の可能性を探るために行われたもので, 氷床西側斜面の海抜 $200 \mathrm{~m}$ の最低部から $1100 \mathrm{~m}$ の均衡線付近までを対象とた。 8 年間夏季および 冬季収支を氷床南部から中部の北緯 $70^{\circ}$ まで測定 しており，その後行われることとなった氷床全域 の消耗量の計算に最も重要な基礎資料を提供した (H.H. Thomsen, personal communication)。消 耗量を求めるには大別して Stake Method のよう な水河学的方法と気象学的方法とがある。水床全 体のような大きな対象には気象学的方法が適して おり，熱収支測定による場合と夏の気温による実 験式で求める場合があるが，現段階では後者の方 が水床全体の消耗量を求めるには適している。消 耗のほとんどは表面勾配の急な水床縁辺部で起こ るため,できるだけ解像度の高い地形モデルが必 


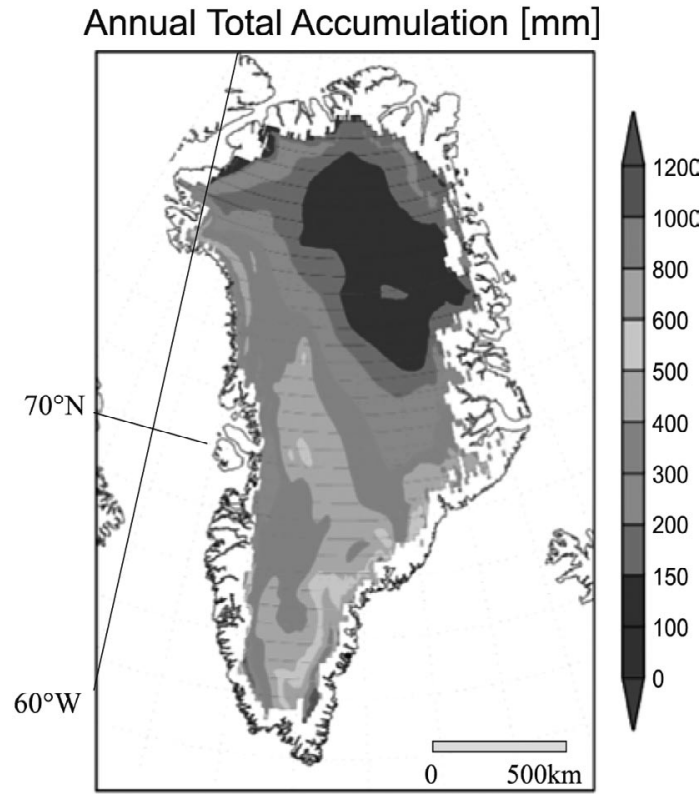

図 7 グリーンランド氷床の年涵養量. Upper percolation zone 以上の約 350 地点で測られた年涵 養量と水床周辺の 40 点における年総計積雪量

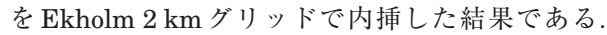
Ohmura et al. (1999) にその後のデータを加え て作成（口絵 2-図 2 参照; 大村, 2010).

Fig. 7 Annual accumulation on Greenland ice sheet. Unit in $\mathrm{mma}^{-1}$. The distribution map is based on the accumulation determined from about 350 pits and ice cores and meteorological snowfall and wind speed observed at 40 stations outside the ice sheet. The accumulation in the region below the upper percolation zone of the ice sheet was interpolated from the $2 \mathrm{~km}$ grid on the Ekholm digital topographic model. Original glaciological and meteorological data are from Ohmura et al. (1999), supplemented by ice core and meteorological data obtained in subsequent years (see to Pictorial 2-Fig. 2; Ohmura, 2010).

要である。この計算は Ekholm（1996）による $2 \mathrm{~km}$ のグリッドのデジタル地形モデル上で Ohmuraの方法（Ohmura et al., 1996）で計算 された消耗量である。

Calving による消耗量は氷河末端が海まで達し ている氷河について個別に計算する以外に方法は なく，大変な労力と経験を必要とする。こうした計 算はまず南西部の水河に関して Weidick（1995）, 北部では Higgins（1991），東岸中部では Reeh
（1994）等の仕事がある。これらを総合した Reeh et al. (1999) の計算結果が現在のところ 最も信頼性が高く水河底面での融水をも考慮して いる。これらの結果を総合して筆者が現在最も妥 当と考えるグリーンランドの氷河の質量収支を表 4 に示す。なおグリーンランドには氷床のほかに 面積で $54,000 \mathrm{~km}^{2}$ の氷床外の小水河群がありこ れらの水河の質量収支もあわせて掲げてある。こ の結果，最も重要な結論はグリーンランドでは水 床もその他の小水河群も現気候下ですでに負の収 支を示していることである。年間の収支 -128 $\mathrm{km}^{3} \mathrm{a}^{-1}$ は海水準にして $0.35 \mathrm{mma}^{-1}$ の上昇に相 当する。この半分は氷床外の小型水河からの流入 である。ここで問題になるのは，この負の収支が 一定であるのか，それとも加速しているのかとい う点である。これについては，グリーンランドの 負の収支の絶対值が増加していると主張する論文 がでている（例えば, Box et al., 2006）。これら の仕事はすべてリモートセンシングによるもの で，誤差を考慮すると，グリーンランドの質量収 支が最近の $20 \sim 30$ 年という比較的短い間に有 意に変化しているかは不明である。直接に質量収 支に結びかねるが，1990 年代より水床上の融雪 融水面積が拡大しており（Abdalati and Steffen, 2001)，氷床の中央部が高度を増したのに対し て，縁辺部では表面が低下しているとの報告があ る(Krabill et al., 2000)。

\section{3）南極水床質量収支の現状}

本来ならここで南極水床の質量収支が扱われる べきである。しかし，現在ある情報をすべて総合 しても南極水床および南極に存在するその他の水 河の質量収支は，正負の符号すらも明らかには提 示できないのが現状である。最も確かな収支項は 表面の涵養量であるが，その值すら大陸平均で $120 \mathrm{mma}^{-1}$ (Giovinette et al., 1990) から 185 $\mathrm{mma}^{-1}$ (Giovinetto and Zwally, 2000) まで分 散している。しかし, 南極水床の質量収支を求め るにあたって最も困難な問題は大陸全体の Calving が解明できていないことと, 氷床の Grounding line 付近と水棚の下面における質量収支の測 定がきわめて難しいことにある。とくに近年わか 
表 4 グリーンランド氷床およびその周辺の山岳水河，氷冠の年質量収支.

Table 4 Annual mass budget of Greenland ice sheet and its marginal mountain glaciers and ice caps.

\begin{tabular}{|c|c|c|c|c|c|c|c|}
\hline \multicolumn{8}{|c|}{ Greenland glaciers mass balance (Total ice covered area: $2,164 \times 10^{3} \mathrm{~km}^{2}$ ) } \\
\hline & \multicolumn{2}{|c|}{$\begin{array}{c}\text { Ice sheet } \\
\left(1,694 \times 10^{3} \mathrm{~km}^{2}\right)\end{array}$} & \multicolumn{2}{|c|}{$\begin{array}{c}\text { Glaciers and ice caps } \\
\left(53.725 \times 10^{3} \mathrm{~km}^{2}\right)\end{array}$} & \multicolumn{2}{|c|}{$\begin{array}{c}\text { Total } \\
\left(1,747.7 \times 10^{3} \mathrm{~km}^{2}\right)\end{array}$} & Source \\
\hline Accumulation & 487 & 288 & 32 & 600 & 519 & 297 & $\begin{array}{l}\text { Weidick (1995); } \\
\text { Bamber and Payne (2004); } \\
\text { Ohmura (2009b) }\end{array}$ \\
\hline Melt ablation & 257 & 152 & 39 & 723 & 296 & 169 & $\begin{array}{l}\text { Ohmura et al. (1999); } \\
\text { Wild et al. }\end{array}$ \\
\hline Calving & 263 & 154 & 53 & 987 & 316 & 181 & $\begin{array}{l}\text { Calanca et al. }(2000) \text {; } \\
\text { Wild et al. }(2003)\end{array}$ \\
\hline Bottom melt & 35 & 21 & 0 & 0 & 35 & 21 & $\begin{array}{l}\text { Reeh (1994); } \\
\text { Reeh et al. }(1999)\end{array}$ \\
\hline Mass budget & -68 & -39 & -60 & $-1,110$ & -128 & -74 & this study \\
\hline
\end{tabular}

りつつあることは Grounding line 付近での融水 がかなり大きな量に達していることである。こう した状況下で氷床の質量収支はもっぱら衛星から の高度測定によっている。III 章 1)節で述べた測 地学的方法である。高度測定による質量収支の方 法は氷河全体を扱わなければ意味をなさない。氷 床の一部分の高度をどんなに正確に換算しても, 水河の質量収支にはならないのである。この方法 による論文は近年数多く出版されているが（例え ば, Thomas et al., 2004; Zwally et al., 2005)，質 量収支という目的に適ったものは今のところ皆無 である。また, 水床以外の小水河群の質量収支も 永年にわたる測定例はきわめてそしい（Fountain et al., 2006)。したがって本論文では，南極大陸 の質量収支を直接には扱わないことにする。

\section{VI. 水河質量収支と海水準の関係}

水河の質量収支は直接その流域の水収支に影響 するが，影響の仕方は気候と地形に大きく左右さ れる。しかしすべての氷河が共通して終局的に影 響するのは海水準であろう。すべての水河のなか には氷棚のように海水と静水圧的な均衡状態にあ る水河も含める。氷棚は質量収支の結果, 崩壊す ることによってその背後の水河の流れが促進され
直接海へ流入して海水準に変化をきたすことは南 極半島東岸のラールセン氷棚 $\mathrm{A}$ および $\mathrm{B}$ の崩壊 の後続現象で観察された。また，氷河以外にも海 水準に変化をきたす現象も多々あり（例えば永久 凍土），これらを包括して 20 世紀に起こった海 水準変化の内訳を表 5 に整理してみる。ここで 重要なことは面積では全球水河水の $3.5 \%$, 容積 ではわずかに $0.3 \%$ しかない山岳水河と水冠が最 も大きな役割を果たしていることである。この夕 イプの水河が， 3 倍以上の面積をもつグリーンラ ンド氷床と同じ量の水を海洋に貢献していること は，小型の水河がいかに敏感に気候変化に反応す るかを物語っている。次に海洋の熱膨張も無視は できない。地球表面での温暖化は，海洋ではすで に3,000 m 以深に達しており, 海洋学のデー夕も 比較的豊富なこともあって，この項が最も正確に 計算できる数值である（Levitus et al., 2005)。 世界に数多く存在する潮汐計から観測期間が長 く, データの質もよくまた地殼の安定している地 域のものを選んで海面上昇を直接推定した結果 (J. Church, personal communication) は表の最 下部に $17 \mathrm{~cm}$ と与えられてある。潮汐計による これまでの仕事もほとんど $15 \sim 17 \mathrm{~cm}$ までの間 に入っているから，100 年間の海面上昇としては 
表 520 世紀における海面上昇量とその内訳.

Table 5 20th Century sea-level change and its components.

\begin{tabular}{lcll}
\hline \multicolumn{1}{c}{ Component } & unit in cm & \multicolumn{1}{c}{ Source } \\
\hline Mountain glaciers and ice caps & 3.7 & This study \\
Greenland (ice sheet, glaciers and ice caps) & 3.5 & This study \\
Thermal expansion of ocean & 2 & based on Levitus et al. $(2005)$ \\
Antarctic ice sheet, glaciers and ice caps, and other sources & 8 & This study \\
Tide gauge interpretation & 17 & J. Church (personal communication) \\
\hline
\end{tabular}

これはかなり信頼してよい。したがって，海面上 昇量総計の $17 \mathrm{~cm}$ とこれまでに説明のついた $9.2 \mathrm{~cm}$ の間に約 $8 \mathrm{~cm}$ という説明のついていない 上昇があったことになる。この説明のつかない $8 \mathrm{~cm}$ の部分は南極大陸の水床・水河と融解しつ つある永久凍土からの質量の流入によると推定さ れている。

\section{VII. 結 論}

全球の小型の山岳水河および水冠とグリーンラ ンド氷床の質量収支をできるだけ実測值に基づい て求めた。小型の水河については 161 の水河で 実測された年収支量を使った。そのうち 35 の水 河では冬季と夏季収支測定が 30 年以上継続され ている。20世紀後半の平均質量収支およびトレ ンドを求めた。1960 年から 2000 年の平均年収 支は - $250 \mathrm{mma}^{-1}$ w.e. $\left(-138 \mathrm{~km}^{3} \mathrm{a}^{-1}\right.$ w.e. $)$ で, その内訳は涵養量 $1470 \mathrm{mma}^{-1}\left(810 \mathrm{~km}^{3} \mathrm{a}^{-1}\right)$, 消耗量 $-1725 \mathrm{mma}^{-1}\left(-950 \mathrm{~km}^{3} \mathrm{a}^{-1}\right)$ である。 この 40 年間の質量収支は負の加速をしており, その率は- $11 \mathrm{mma}^{-2} て ゙$, 原因は融水を主とする 消耗量の増加にある。この間の質量収支の変化 は，厳密にはこのように線形でなく，1945 年を 中心とする消耗量の多かった時期とそれに続く 1960 年から 1980 年代の終わりまでの消耗量の 減少した時期，さらに 1990 年以降現在まで続い ている消耗量の増大期からなる変化をしてきたこ とがわかる。これらの時期はエアロゾルの増減に よって起こる太陽放射の変動, すなわち Global dimming と Global brightening の時期に一致し ており, 20 世紀の水河質量変化は温室効果ガス とエアロゾルの微妙な均衡の崩れの影響であるこ

\section{とがわかる。}

グリーンランド氷床と周辺部の氷河は現段階で すでに負の質量収支を担っており，平均年正味 収支は- $74 \mathrm{mma}^{-1}$ (総計で- $128 \mathrm{~km}^{3} \mathrm{a}^{-1}$ ), 内訳 は涵養量 $297 \mathrm{mma}^{-1}\left(519 \mathrm{~km}^{3} \mathrm{a}^{-1}\right)$, 融水による 消耗量 $-169 \mathrm{mma}^{-1}\left(-296 \mathrm{~km}^{3} \mathrm{a}^{-1}\right)$, Calving による消耗量 $-181 \mathrm{mma}^{-1}\left(-316 \mathrm{~km}^{3} \mathrm{a}^{-1}\right)$, 底 の融解 $-21 \mathrm{mma}^{-1}\left(-35 \mathrm{~km}^{3} \mathrm{a}^{-1}\right)$ である。現 段階ではこの収支と各項の永年変化を求めること は難しい。定性的ではあるが水床上での融解面積 がこの 10 年間で拡大したとの報告がある。南極 水床の収支は現段階では論じることは不可能であ る。

総括して 20 世紀における海水準の増昇のうち, 山岳水河および氷冠は $3.7 \mathrm{~cm}$, グリーンランド は $3.5 \mathrm{~cm}$, 海水の熱膨張 $2 \mathrm{~cm}$ で総計して $9.2 \mathrm{~cm}$ であり, 潮汐計から求められた $17 \mathrm{~cm}$ との間に 約 $8 \mathrm{~cm}$ の差がある。この差の少なくとも一部は おもに南極大陸からの水床と水河の質量流入に起 因すると思われる。

\section{謝 辞}

この論文を完成するにあたって, 多くの研究者のご 好意によって, 出版前の質量収支に関するデー夕をい ただいた。とくにマンチェスター大学の Roger Braithwaite, ストックホルム大学の Peter Jansson, カナダ地質調查所の Mike Demuth, コロラド大学の Mark Dyurgerov, グルノーブル大学の Christian Vincent, バイエルン科学アカデミーの Ludwig Braun, ノルウェー極地研究所の Jack Kohler, E.T.H. の Andreas Bauder, おょ び World Glacier Monitoring Service の Wilfried Haeberli, Michael Zempの諸氏に心から感謝の意を表します。 


\section{文献}

Abdalati, W. and Steffen, K. (2001): Greenland ice sheet melt extent: 1979-1999. Journal of Geophysical Research, 106 (D24), 33983-33988.

Aellen, M. (1995): Glacier mass balance studies in the Swiss Alps. Zeitschrift für Gletscherkunde und Glazialgeologie, 31, 159-168.

Bales, R.C., Guo, Q., Shen, D., McConnell, J.R., Du, G., Burkhart, J.F., Spikes, V.B., Hanna, E. and Cappelen, J. (2009): Annual accumulation for Greenland updated using ice core data developed during 2000-2006 and analysis of daily coastal meteorological data. Journal of Geophysical Research, 114, D06116, doi:10.1029/2008JD011208.

Bamber, J.A. and Payne, A.J. eds. (2004): Mass Balance of the Cryosphere. Cambridge, Cambridge University Press.

Benson, C.S. (1961): Stratigraphic studies in the snow and firn of the Greenland Ice Sheet. Folia Geographica Danica, 9, 13-37.

Benson, C.S. (1962): Stratigraphic studies in the snow and firn of the Greenland Ice sheet. Research Report, No.70, Snow, Ice, and Permafrost Research Establishment (SIPRE), 93p.

Box, J.E., Bromwich, D.H., Veenhuis, Bai, L., Stroeve, J.C., Rogers, J.C., Steffen, K., Haran, T. and Wang, S. (2006): Greenland ice sheet surface mass balance variability (1988-2004) from calibrated Polar MM5 output. Journal of Climate, 19, 2783-2800.

Calanca, P., Gilgen, H., Ekholm, S. and Ohmura, A. (2000): Gridded temperature and accumulation distributions for use in cryospheric models. Annals of Glaciology, 31, 118-120.

Chen, J. and Funk, M. (1990): Mass balance of Rhonegletscher during 1882/83-1986/87. Journal of Glaciology, 36, 199-209.

Chen, J. and Ohmura, A. (1990): Estimation of Alpine glacier water resources and their change since 1870s. in Hydrology in Mountainous Regions I edited by Lang, H. and Musy, A., IAHS Publication, 193, 127-135.

Ekholm, S. (1996): A full coverage, high resolution, topographic model of Greenland computed from a variety of degitsl elevation data. Journal of Geophysical Research, 101 (B10), 21961-21972.

Fountain, A.G., Nylen, T.H., MacClune, K.L. and Gayle, L. (2006): Glacier mass balances (1993-2001), Taylor Valley, McMurdo Dry Valleys. Journal of Glaciology, 52, 451-462.

藤井理行 $(2005)$ : 水床, 水流, 棚水, 水山. 日本雪水 学会監：雪と氷の辞典，第 9 章 極地水床，9.2.1 (1) 節. 330-335.

Giovinetto, M.B. and Zwally, H.J. (2000) : Spacial distribution net surface accumulation on the Antarctic ice sheet. Annals of Glaciology, 31, 171-178.

Giovinetto, M.B., Waters, N.M. and Bentley, C.R.
(1990): Dependence of Antarctic surface mass balance on temperature, elevation, and distance from open ocean. Journal of Geophysical Research, 95 (D4), 3517-3531.

Higgins, A.K. (1991): North Greenland glacier velocities and calf ice production. Polarforschung, 60 (1), 1990, 1-23.

Krabill, W., Abdalati, W., Frederick, E., Manizade, S., Martin, C., Sonntag, J., Swift, R., Thomas, R., Wright, W. and Yungel, J. (2000): Greenland ice sheet: High-elevation balance and peripheral thinning. Science, 289, 428-430.

Kuhn, B.F. (1787): Versuch über den Mechanisms der Gletscher. Magazin Naturkunde Helvetians, Nr.1.

Levitus, S., Antonov, J. and Boyer, T. (2005): Warming of the world ocean. Geophysical Research Letters, 32, L02604, doi:10.1029/2004GL021592.

Mercanton, P.-L. (1915): Le glacier du Rhone. in Vermessungen am Rhone Gletscher 1874-1915 edited by Mercanton, P.-L., Gletscher Kommission der schweizerischen Naturforschenden Gesellschaft Kommissions Verlag, Basel, 37-190.

Müller, F. (1962): Zonation in the accumulation area of the glaciers of Axel Heiberg Island, N.W.T., Canada. Journal of Glaciology, 4, 302-313.

Ohmura, A. (1987): New temperature distribution maps for Greenland. Zeitschrift für Gletscherkunde und Glazialgeologie, 23, 1-45.

Ohmura, A. (2004): Cryosphere during the twentieth century. in The State of the Planet: Frontiers and Challenges in Geophysics edited by Sparks, R.S.J. and Hawkesworth, C.J., Geophysical Monograph, 150, American Geophysical Union, 239-257.

Ohmura, A. (2006): Changes in mountain glaciers and ice caps during the $20^{\text {th }}$ century. Annals of Glaciology, 43, 361-368.

Ohmura, A. (2009a): Observed decadal variations in surface solar radiation and their causes. Journal of Geophysical Research, 114, D00D13, doi:10.1029/ 2008JD011290.

Ohmura, A. (2009b): Completing the World Glacier Inventory. Annals of Glaciology, 53, 1-5.

大村 纂 (2010): 世界 17 水河域の年質量収支の長期 変動およびグリーンランド氷床の年涵養量. 地学雑 誌, 119, iv.

Ohmura, A. and Lang, H. (1989): Secular variation of global radiation in Europe. in IRS'88: Current Problems in Atmospheric Radiation edited by Lenoble, J. and Geleyn, J.-F., A. Deepak Publ., Hampton, VA, 298-301.

Ohmura, A. and Reeh, N. (1991): New precipitation and accumulation distribution maps for Greenland Journal of Glaciology, 37, 140-148.

Ohmura, A., Wild, M. and Bengtsson, L. (1996): A possible change in mass balance of Greenland and Antarctic ice sheets in the coming century. Journal 
of Climate, 9, 2124-2135.

Ohmura, A., Calanca, P., Wild, M. and Anklin, M. (1999): Precipitation, accumulation and mass balance of the Greenland ice sheet. Zeitschrift für Gletscherkunde und Glazialgeologie, 35, 1-20.

Quervain, A. de and Mercanton, P.-L. (1920): Ergebnisse der schweizirischen Grönlandexpedition 1912-1913. Denkschrift der Schweizerischen Naturforschenden Gesellschaft, 53, 145-151.

Reeh, N. (1994): Calving from Greenland glaciers: Observations, balance estimates of calving rates, calving laws. in Workshop on the Calcing Rate of West Greenland Glaciers in Response to Climate Change, 13-15 September 1993, Copenhagen, Danish Polar Center edited by Reeh, N., 85-102.

Reeh, N. and Olesen, O.B. (1986): Velocity measurements on Daugaard-Jensen Gletscher, Scoresby Sund. East Greenland. Annals of Glaciology, 8, 146-150.

Reeh, N., Mayer, Christoph, Miller, H., Thomsen, H.H. and Weidick, A. (1999): Present and past climate control on fjord glaciations in Greenland: Implications for IRD-deposition in the sea. Geophysical Research Letters, 26, 1039-1042.

Thomas, R., Rignot, E., Casassa, G., Kanagaratnam, P., Acuña, C., Akins, T., Brecher, H., Frederick, E.,
Gogineni, P., Krabill, W., Manizade, S., Ramamoorthy, H., Rivera, A., Russell, R., Sonntag, J., Swift, R., Yungel, J. and Zwally, J. (2004): Accelerated sea level rise from West Antarctica. Science, 306, 255258.

Weidick, A. (1995): Greenland: Satellite Image Atlas of the World. Professional Paper, 1386-C, U.S. Geological Survey, US Government Printing Office, Washington, D.C., 141p.

Wild, M., Calanca, P., Scherrer, S.C. and Ohmura, A., (2003) : Effects of polar ice sheets on global sea level in high-resolution greenhouse scenarios. Journal of Geophysical Research, 108 (D5), 4165, ACL 5-110.

Wild, M., Gilgen, H., Roesch, A. and Ohmura, A. (2005): From dimming to brightening: Decadal changes in solar radiation at the Earth's surface. Sience, 308, 847-850.

Zwally, H.J., Giovinetto, M.B., Li, J., Cornejo, H.G., Beckley, M.A., Brenner, A.C., Saba, J.L. and Yi, D. (2005): Mass changes of the Greenland and Antarctic ice sheets and shelves and contributions to sea-level rise: 1992-2002. Journal of Glaciology, 51, 509-527.

( 2010 年 1 月 22 日受付, 2010 年 3 月 8 日受理) 